\title{
The contribution of lithic production systems to the interpretation of Mousterian industrial variability in south-western France: The example of Combe-Grenal (Dordogne, France)
}

\author{
J ean-Philippe Faivre, Emmanuel Discamps, Brad Gravina, Alain Turq, \\ J ean-Luc Guadelli, Michel Lenoir
}

\section{Keywords:}

Mousterian variability

Combe-Grenal

Primary flaking strategies

Raw material provisioning strategies

Techno-economy

Neandertals

\begin{abstract}
Disentangling the relative contribution of the various factors underlying Middle Palaeolithic industrial variability remains one of the foremost problems for researchers interested in Neandertal technological and behavioural adaptations. The site of Combe-Grenal (Dordogne) has figured prominently in these discussions given its long stratigraphic sequence and rich archaeological record that extends from MIS 6 to MIS 3 and contains all of F. Bordes' Mousterian facies. Departing from a strict typological approach, we provide a revised vision of the site's sequence focused on individualising lithic production systems. We investigate to what extent typologically different industries, beyond their separation imposed by the very idea of discrete Mousterian facies, nevertheless portray comparable production systems. By eschewing a chronology of the traditional Mousterian facies, our technological approach to the Combe-Grenal assemblages succeeded in identifying a clear stratigraphic succession where strictly typological approaches had previously failed. Moreover, comparison with other regional sequences shows the succession of Mousterian technological systems identified at Combe-Grenal not to be an exception in south-western France. We propose a revised chronology for the site's sequence based on a correlation of changes in the structure of regional faunal communities with independent palaeo-environmental data. Finally, comparing technological data with raw material provisioning strategies and elements of faunal exploitation, such as prey availability, provides insights concerning the interpretation of Mousterian variability and the investigation of changing patterns of Neandertal landscape use.
\end{abstract}

\section{Introduction}

Archaeological perspectives on Neandertal behavioural capacities remain a source of long-standing debate and have come to include a variety of interrelated and sometimes contradictory approaches integrating material, demographic, and social elements. These new research paradigms have also recently benefited from the development of regional environmental proxies and an expanded corpus of numerical dates providing important new contextual information (e.g. Guibert et al., 2008; Sánchez-Goni et al., 2008; Discamps et al., 2011; Guérin et al., 2012). Many of these competing ideas have, not surprisingly, taken the rich and varied Mousterian occupation of southwestern France as an ideal testing ground. Over the last 60 years, our conception of this region's Middle Palaeolithic record has traversed several successive stages characterised by different theoretical perspectives and methodologies. From the development of François Bordes' typological approach during the course of the 1950s emerged the original definitions of the different Mousterian facies that are still in use today (Bordes and Bourgon, 1951; Bordes, 1953, Bordes, 1981). These industrial entities, characterised essentially by the relative frequencies of retouched tools, fixed the limits of what is now commonly referred to as "Mousterian variability". Once defined, these facies - "Typical", "Ferrassie", "Quina", "Mousterian of Acheulean Tradition" (MTA), and "Denticulate" - formed the basis for several interpretative models held to account for their variability. In order to avoid any terminological confusion, Bordes' typologically defined Mousterian facies areplaced in quotations throughout this paper. For Bordes, who maintained that each of his 
retouched tools types reflected a behavioural reality, which, when summed, represented normative stylistic traditions, defended the idea that behind his five Mousterian facies lay separate contemporaneous cultural phyla (Bordes and Bourgon, 1951; Bordes, 1961). With the emergence of the New Archaeology and its dissatisfaction with cultural-historical approaches came the cultural ecology influenced "functional model" of L. and S. Binford (Binford and Binford, 1966, 1969; Binford, 1973, 1977, 1989). Here, variations in tool frequencies were interpreted simply as different tool-kits geared around varying tasks, most notably butchery and woodworking.

Roughly contemporary with the so-called Bordes-Binford debate, Mellars (1965, 1969, 1970, 1988, 1989, 1996) introduced a chronological dimension to the debate based on his reading of the relative stratigraphic superimposition of Bordes' three major industrial variants ("Ferrassie", "Quina", "MTA"). While the general significance of the "Typical" and "Denticulate" variants remains a "largely open question" (Mellars, 1992:39), the explanation of a clear chronological separation of the more distinctive ones as being tied to unrelated technological traditions recalls certain aspects of Bordes' perception of the 'cultural' or 'behavioural' character of Middle Palaeolithic variability. Although Mellars' model loosely touches upon related issues of resource availability, site function, and environmental influences, the alternative tool reduction hypothesis of $\mathrm{H}$. Dibble and $\mathrm{N}$. Rolland (Dibble, 1984, 1987, 1995; Rolland, 1981, 1988; Dibble and Rolland, 1992, Rolland and Dibble, 1990) integrates them as principle causative factors. The central tenant of the reduction model is the typological plasticity of Bordes' variants whereby the progressive resharpening/reduction of blanks and retouched tools as a function of both occupation intensity and proximity to raw materials effectively controls the frequencies of retouched tools types in particular assemblages. In questioning the reality of Bordes' variants as discrete industrial entities, Dibble and Rolland emphasise the role of raw material contingencies and occupation intensity against their climatic backdrop, including biomass fluctuations, as the most parsimonious explanation of Middle Palaeolithic assemblage variability.

What is clear from the above is that, sixty years on, the significance of Mousterian variability in south-western France remains not only a topic of great interest but appears no closer to being satisfactorily resolved. A substantial obstacle inhibiting a clearer, more holistic understanding of this variability lies, in our opinion, with the multiplicity of analytical approaches privileging either typology or technology, or those that combinedifferent elements of both (i.e., techno-typological approaches). Moreover, this relative wealth of approaches can easily confound the non-specialist: for example, the "Quina Mousterian", as defined by the typological approach of Bordes (1961), differs considerably from that derived from a consideration of Quina reduction strategies as madeevident in thetechnological analyses of $\operatorname{Turq}(1988,1992)$ and Bourguignon (1997). This paradox is largely due to thepersistence of blurred and ambiguous definitions of particular lithic techno-complexes (LTC) in recent techno-typological approaches, where the relative importance of typological elements, on the one hand, and technological arguments, on the other, are rarely made explicit.

One of the primary goals of this article is an attempt to untangle typology from technology such that current issues surrounding Late Mousterian assemblage variability in south-western France emerge clearer and framed more succinctly theoretically. Retouched tool types, historically considered typical of particular Mousterian facies, are influenced by the management of raw materials and concomitant technical demands of the production system, as well as being adaptable to specific contexts and differing economic decisions. Here we investigate to what extent typologically different industries, beyond their separation imposed by the very idea of discrete Mousterian facies, nevertheless portray identical production systems. Finally, building on the chrono-cultural approach first developed by Mellars and eschewing the chronology of traditional typological variants as much as possible, we instead focus attention on the temporal succession of Mousterian production systems (Delagnes and Meignen, 2006; Faivre, 2011).

\section{Material and Methods}

\subsection{The Combe-Grenal sequence}

South-western France, and especially the Perigord region, is well known for its long tradition of archaeological research and rich Palaeolithic record. Amongst the region's numerous Middle Palaeolithic sites, including open-air localities, is the substantial archaeological sequence documented at Combe-Grenal (Dordogne, France; Fig. 1) by F. Bordes between 1953 and 1965. This 13-m thick deposit spread across three superimposed rocky terraces contains 55 Middle Palaeolithic layers. The final part of the sequence (layers 1-37; Fig. 2) on the uppermost terrace has produced an unequalled archaeological, climatic, and environmental record of the region's Mousterian occupation. Moreover, the diversity of the various industries documented at the site not only contributed to the original definition of Bordes' Mousterian variants but also the various interpretive models (see above) held to account for their variability both in south-western France and further afield. The study of material recovered from Combe Grenal has also allowed specific techno-economic aspects of particular reduction sequences (Geneste et al., 1997; Turq, 2000; Bourguignon and Turq, 2003; Bourguignon et al., 2004; Faivre,2011) as well as patterns of scraper production and maintenance (Lenoir, 1986; Panabieres, 1989), the reduction of notched tools (Hiscock and Clarkson, 2007), or the function of different tool-kits (Anderson-Gerfaud, 1981; Beyries and Walter, 1996) to be explored in greater detail.

Based on information gleaned essentially from Bordes' excavation notebooks, Dibble et al. (2009) have recently highlighted certain

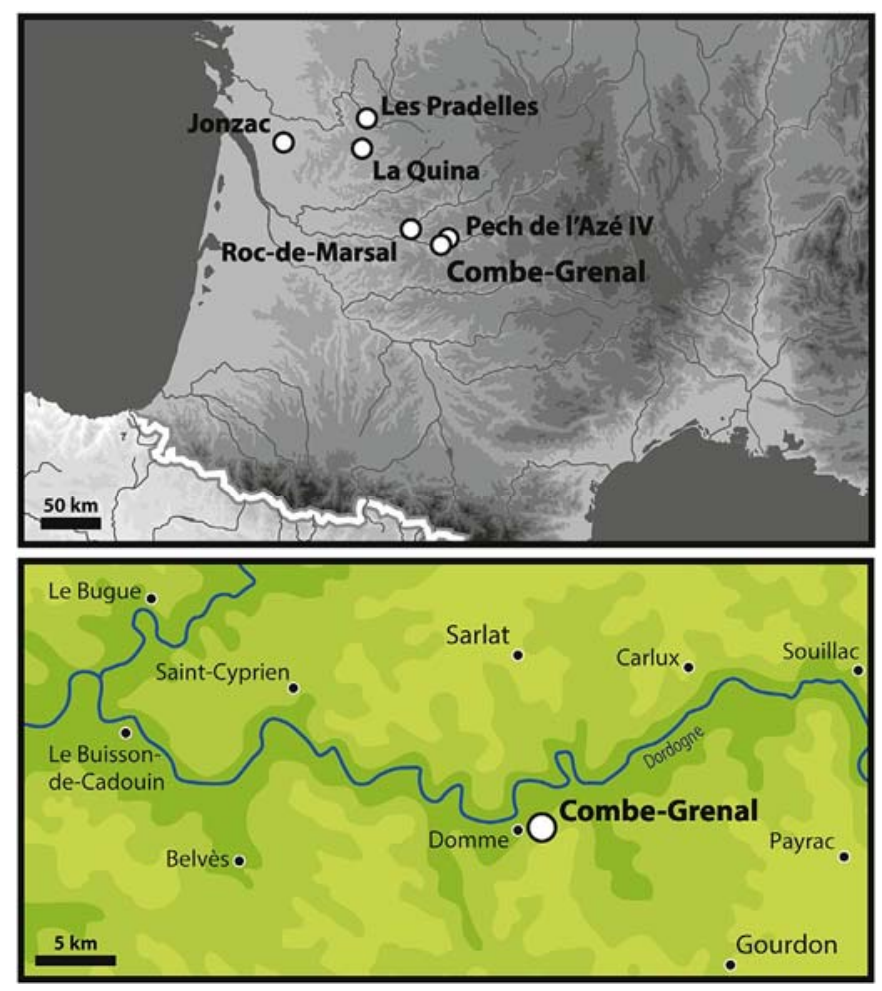

Fig. 1. Location of Combe-Grenal. 


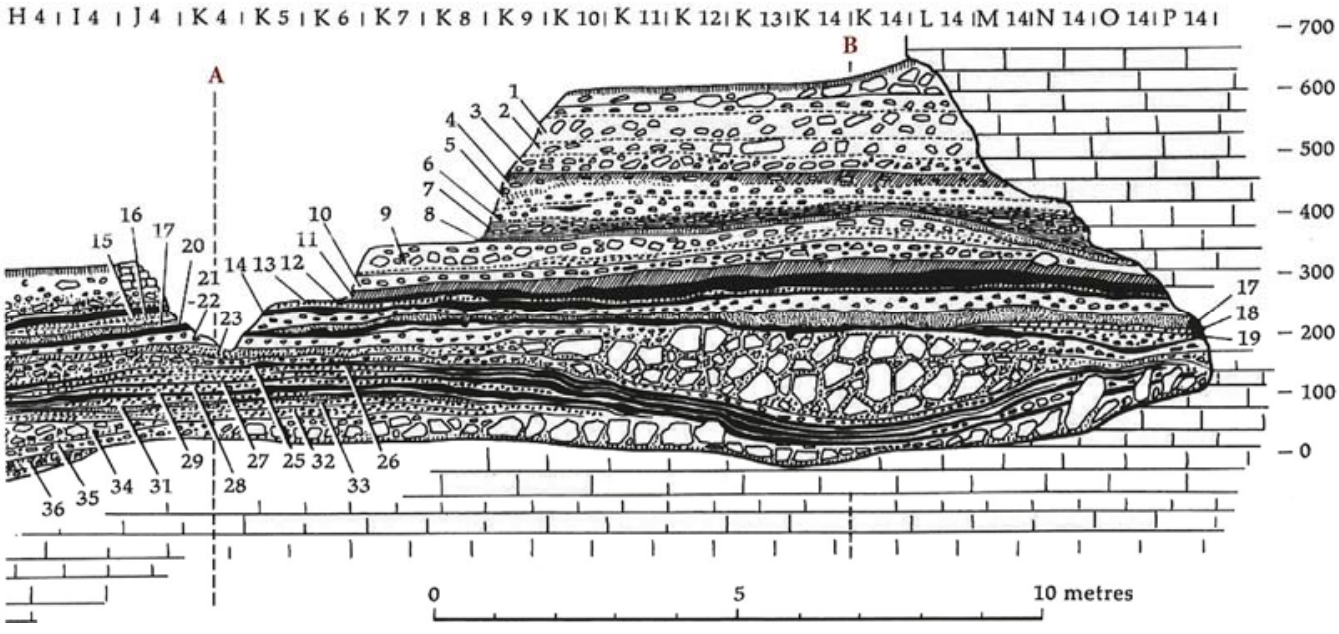

Fig. 2. Stratigraphy of the uppermost terrace at Combe-Grenal (after Bordes, 1972).

problems with the stratigraphic integrity of particular lithic assemblages from Combe-Grenal currently housed at the Musee national de Préhistoire (Les Eyzies de Tayac). These authors focus particular attention on problems evident in the existing documentation concerning these contexts (excavation notebooks and spatial data) as well as cumulative errors connected to the repeated manipulation of the material over numerous years. Despite the reality of these problems and their not unsubstantial implications for the study of this material, these biases are stratigraphically inconsistent and only differentially affect the Combe-Grenal assemblages. Moreover, in pointing out these issues, Dibble et al. do not question the chrono-cultural model whereby the "Quina Mousterian" succeeds the "Ferrassie Mousterian". In our view, neither the feasibility of a technological analysis of the lithic material nor an investigation of associated raw material economies is in any great way compromised by these issues. This assertion is supported by recent studies (Faivre, 2011, 2012) demonstrating that these types of analyses, when applied to several successive layers, produce coherent results revealing broad technoeconomic trends during the course of the last glaciation.

\subsection{Methodology}

Over the last few decades, research focused on Middle Palaeolithic industries has distinguished different lithic production systems characterised by a specific type of debitage. Currently, several such production systems have been identified according to the exclusive

use of a particular primary flaking strategy combined with a consideration of their variability: Levallois (Boëda and Pelegrin, 1983; Boëda et al. 1990; Van Peer, 1992; Boëda 1994; Dibble and Bar-Yosef, 1995; Scott, 2011), Discoid (Boëda, 1993; Jaubert, 1994; Locht and Swinnen, 1994; J aubert and Mourre, 1996; Peresani, 1998; Bourguignon and Turq, 2003), Quina (Turq, 1989, 1992; Bourguignon, 1996; Hiscock et al., 2009), trifacial (Boëda, 1991; Chevrier, 2006), Clactonian (Ashton et al.,1992), a system of alternating debitage surfaces or SSDA (Forestier, 1993; Boëda 1997), bifacial shaping (Boëda, 1996; Soressi, 2002), or Mousterian blade production (Boëda, 1988; Otte et al.

\section{0; Meignen, 1995; Révillion, 1995)}

Our technological approach is essentially based on the conceptof the chaîne opératoire ramifiée or ramified reduction sequence (Geneste, 1991; Bourguignon et al., 2004; Faivre, 2011), also referred to as dendriticreduction sequence(Delagnesand Rendu, 2011), that aimsto reconstruct economic considerations and behavioural choices underlying raw material use. Sub-divided into two interrelated operational stages, ramifiedreductionsequencesinitiallyinvolveblock-cores supplying predetermined technical and functional products as well as sub-products (cortical or management flakes) that are then used as blanks (core-flakes) to produce a variety of secondary products with different morpho-technical and functional characteristics.

When this type of analysis is applied to the Combe-Grenal material, it becomes clear that each lithic production system functions according to its proper technical rules that themselves portray techno-economic concerns tied to different objectives, including, but by no means limited to, retouched tools. For instance, certain assemblages have a lowor extremely limited retouched tool component leading to their being attributed to the "Typical" (e.g. layers 29-30) or "Denticulate Mousterian" (e.g. layer 38) by default. However, this limited proportion of retouched tools is often counterbalanced by an abundance of diverse, unmodified, and sought after end-products that are themselves the principle production objective.

While previous technological studies (Pelegrin, 1990; Delagnes, 1992; Turq, 2000; Bourguignon and Turq, 2003; Thiébaut, 2005; Faivre, 2011) of material from the upper layers of the Combe

Grenal sequence determined general trends in primary flaking strategies (Table 1), more recent work added further precision concerningtechno-economicaspects. Therevision of theCombe-Grenal sequence presented here is based on either detailed technological analyses or qualitative aspects of certain layers, complemented by already published information (see Table 1 for details).

Table 1

Combe-Grenal, upper terrace. Mousterian facies (after Bordes, 1972, 1981) and associated production systems.

\begin{tabular}{llll}
\hline Layer & Mousterian facies & $\begin{array}{l}\text { Technological } \\
\text { system }\end{array}$ & References \\
\hline $1-4$ & "Mousterian of & Discold & Pelegrin 1990; this study \\
& Acheulean Tradition" & $\begin{array}{l}\text { Bifacial shaping } \\
\text { Non-Levallois }\end{array}$ & \\
& & laminar & \\
& & Discoid/ Levallois & Faivre 2011, this study \\
$5-6$ & "Typical" & Levallois & Faivre 2011, this study 8- \\
7 & "Typical" & Discoid/ Levallois & This study \\
10 & "Typical" & Discoid & Thíbaut 2005; Faivre 2008 \\
$11-12$ & "Denticulate" & Discoid & Bourguignon and Turq 2003 \\
$13-15$ & "Denticulate" & Levallois/ Discoid & Faivre 2011 \\
16 & "Denticulate" & Bladelet & \\
& & technology & \\
$17-19$ & "Evolved Quina" & Quina & Faivre 2011 \\
20 & "Denticulate" & Quina & Faivre 2009-2010 \\
$21-26$ & "Classic Quina" & Quina & Turq 2000 \\
27 & "Ferrassie" & Levallois & Faivre 2008 \\
$28-31$ & "Typical" & Levallois & Faivre2011 \\
$32-35$ & "Ferrassie" & Levallois & Delagnes 1992, Faivre 2011 \\
$36-37$ & "Typical" & Levallois & Faivre 2011 \\
\hline
\end{tabular}


3. Results

3.1 Layers 35-27: the Levallois system and comparison between the "typical" and "Ferrassie" variants

Layers 31 through 28, as well as 37 and 36, are all assigned to the "Typical Mousterian" and found inter-stratified with "Ferrassie" assemblages (layers 35-32) in the heart of the Combe-Grenal sequence. Bordes' (1955) original publication qualified layers 28-30 as "attenuated Ferrassie Mousterian", which he subse- quently reattributed to the "Typical Mousterian" nearly 20 years later in his synthesis of the Combe-Grenal sequence, "A Tale of Two Caves" (Bordes, 1972). This alteration was most likely motivated by the development of his analytical method and the relative impor- tance of its different typological indexes.
However, while genuine differences certainly exist between these groups of assemblages, a closer examination of the original attributions of layers 28 through 30 is revealing. Focusing on the assemblages from layers 29-30 and 27, assigned, respectively, to the "Typical" and "Ferrassie Mousterian", it is possible to demonstrate that they all share common technological features (Fig. 3). Both share the same methods and conceptions of flake production, recurrent uni- and bipolar Levallois debitage, that, although subject to some insignificant quantitative variation, remain extremely homogeneous (e.g., differences in the proportions of Levallois cores are not statistically significant, $\mathrm{chi}^{21} 1 \mathrm{1} .223$; $\mathrm{p}>0.05$; cf. Table 2). This consistency is reinforced by both the morphology and dimensions of similar sought-after Levallois products that could be used unmodified or transformed by retouch. In terms of this retouched tool component, both the variety and respective

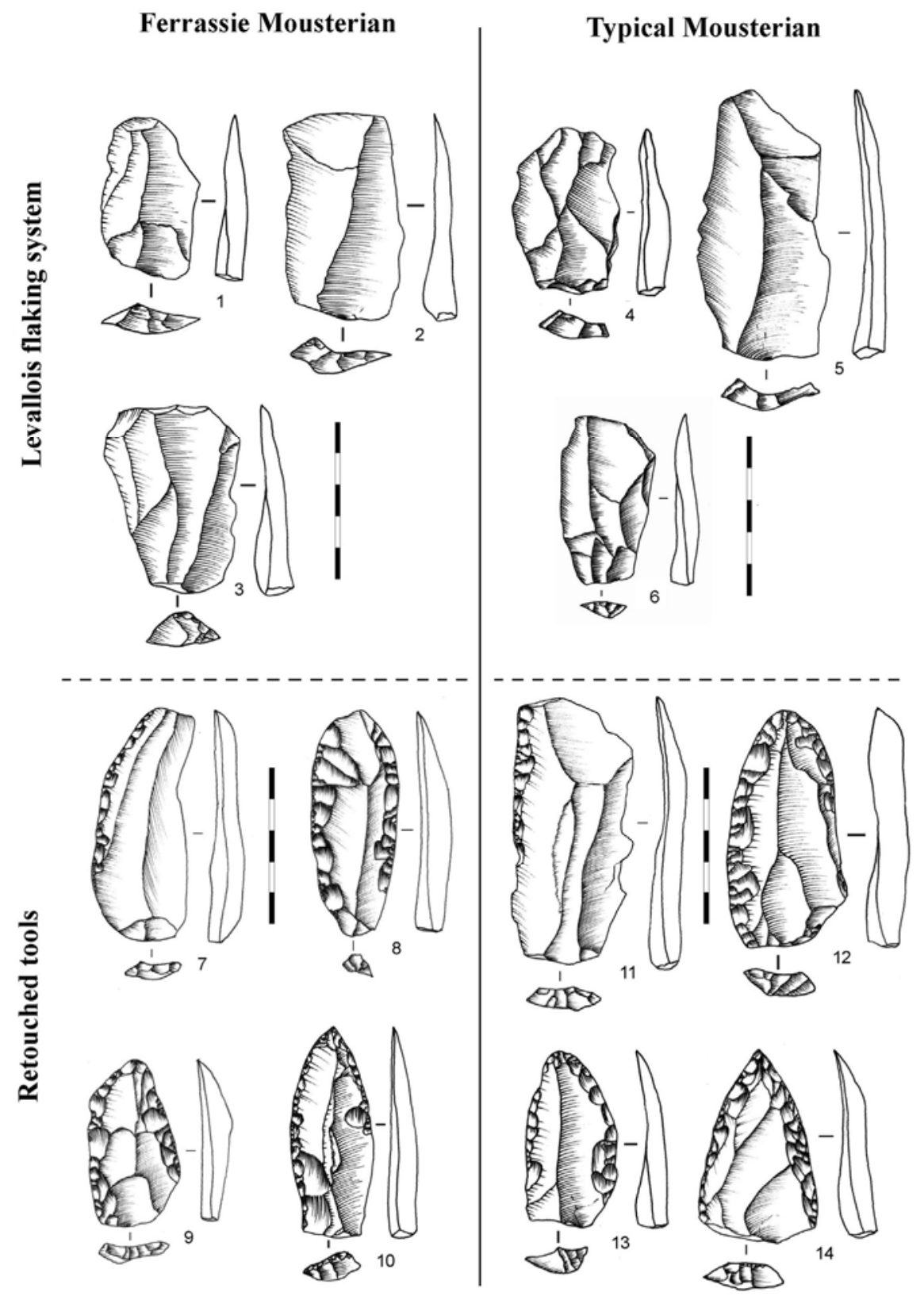

Fig. 3. Comparison of the Levallois production system in the "Ferrassie" (layer 27) and "Typical Mousterian" (layer 29 and 30) of Combe Grenal. 1-6: unretouched Levallois flakes; 7, 11: single side scrapers; 8-10 and 12-14: convergent scrapers and Mousterian points. 
frequency of tool types are remarkably consistent (Table 3). Single or double scrapers (including convergent and Mousterian points) occur in high frequencies (differences between layers are not statistically significant, $\operatorname{chi}^{2} 10.036 ; \mathrm{p}>0.05$ ), while notches (Clactonian or retouched) and denticulates are less common and remain quantitatively consistent between the two industries (differences between layers are not statistically significant for notches, chi $^{2}$ 1/4242; p > 0.05, but are, albeit not by much, statistically significant for denticulates $\mathrm{chi}^{2}{ }^{1} 4.106$; $\left.\mathrm{p}<0.05\right)$. In terms of debitage economy, retouched tools are produced on two broad categories of blanks, Levallois products and partially cortical flakes. In addition to similarities in blank selection, coherent functional characteristics (retouch intensity, delineation of the retouched edges, working edge angles) reveal more or less identical processes of transforming the tool's active edges.

Table 2

Percentages of Levallois products (retouched or not) and cores for "Ferrassie Mousterian" (layer 27) and "Typical Mousterian" (layer 29-30).

\begin{tabular}{lcccc}
\hline & \multicolumn{2}{c}{ Ferrassie layer 27 } & \multicolumn{2}{c}{ Typical layers 29-30 } \\
\hline Unretouched Levallois product & 196 & $50 \%$ & 306 & $63 \%$ \\
Retouched Levallois product & 198 & $50 \%$ & 178 & $37 \%$ \\
Total & 394 & 100 & 484 & 100 \\
Levallois Cores & 39 & $68 \%$ & 48 & $77 \%$ \\
\hline
\end{tabular}

Table 3

Retouched tool counts for the "Ferrassie Mousterian" (layer 27) and "Typical Mousterian" (layers 29 and 30).

\begin{tabular}{|c|c|c|c|c|}
\hline & \multicolumn{2}{|c|}{ Ferrassie layer 27} & \multicolumn{2}{|c|}{ Typical layers 29-30 } \\
\hline & $\mathrm{N}$ & $\%$ & $\mathrm{~N}$ & $\%$ \\
\hline Single scrapers & 127 & $39 \%$ & 134 & $37 \%$ \\
\hline Double scrapers & 43 & $13 \%$ & 48 & $13 \%$ \\
\hline Convergent scrapers & 25 & $8 \%$ & 32 & $9 \%$ \\
\hline Mousterian points & 14 & $4 \%$ & 16 & $4 \%$ \\
\hline Déjetéscrapers & 40 & $12 \%$ & 17 & $5 \%$ \\
\hline Transverse scrapers & 12 & $4 \%$ & 3 & $1 \%$ \\
\hline End-scrapers (typical/atypical) & 1 & $0.3 \%$ & 3 & $1 \%$ \\
\hline Truncations & 1 & $0.3 \%$ & 2 & $0.5 \%$ \\
\hline Backed knives & 1 & $0.2 \%$ & 3 & $1 \%$ \\
\hline Perçoirs & 1 & $0.2 \%$ & 2 & $0.5 \%$ \\
\hline Clactonian notches & 6 & $2 \%$ & 15 & $4 \%$ \\
\hline Retouched notches & 13 & $4 \%$ & 14 & $4 \%$ \\
\hline Denticulates & 23 & $7 \%$ & 42 & $11 \%$ \\
\hline Composite retouched tools & 21 & $6 \%$ & 34 & $9 \%$ \\
\hline Total & 328 & $100 \%$ & 365 & $100 \%$ \\
\hline
\end{tabular}

The main difference between the assemblages ultimately resides in retouched tool frequencies, which are on average two times higher in the "Ferrassie" contexts (12\% in layers 29-30, 24\% in layer 27; differences are highly statistically significant, chi $^{2} \quad 1 / 4 \quad 171.508$; $\mathrm{p}<0.001)$. Moreover, this higher frequency is accompanied by an elevated representation of resharpening flakes that translates as a clear marker of more intense tool reduction (5\% in layers $29-30$, $17 \%$ in layer 27; differences are highly statistically significant, $\mathrm{chi}^{2}$ 257.9; $\mathrm{p}<$ 0.001). This character is also clearly apparent with double and convergent scrapers, some of which bear scaled and occasionally stepped retouch indicative of more prolonged reduction sequences, as anticipated in Dibble's reduction model (1987, 1995).

While the "Typical" and "Ferrassie" industries share the same method (Levallois) for producing blanks with predetermined morphologies, the frequency and intensity in which they are retouched and resharpened clearly differs. Although drawn from a common technological base, these differences may very well represent varying functional and economic choices with a temporal significance. The variability of these assemblages effectively consists in the respective emphasis accorded to retouched tools and unmodified debitage products. This notion of economic and functional mechanisms or concerns underlying Levallois debitage is similarly echoed in the overlying Quina industries.

\subsection{Layers 26 to 17: internal variability of the Quina production} system. The example of layer 20

The Combe-Grenal sequence also contains evidence for the internal variability of the "Quina Mousterian", where the major element separating the 'classic' from 'evolved' forms is the increased importance of notched and denticulated tools in the latter (LeTensorer, 1978; Turq, 1979). In this developmental model, traditionally considered as linear, a stark rupture is evident with layer 20 assigned to the "Denticulate Mousterian" by Bordes (1955 1972). A recent re-analysis of this layer (Faivre, 2011) identified several elements that place it squarely within the diachronic variability of Quina reduction strategies at Combe-Grenal (layers 26-21 and 19-17). In both these groups of assemblages, as well as in layer 20, flake production is identical both in terms of debitage economy (the reduction of blocks/nodules and flakes) and production objectives (thick asymmetrical flakes, Fig. 4). The fact that two typologically different assemblages can nevertheless share the same technology has previously been identified by Dibble's (1995) comparison of layers 22 and 25 of Combe-Grenal with the material from Combe-Capelle Bas.

The second point of coherence specifically concerns functional options (i.e., transformation of Quina debitage products) responsible for the original attribution of layer 20 to the "Denticulate Mousterian". For instance, clear differences are perceptible in the transformation of flake blanks between layers 17 and 20, which are dominated, respectively, by scrapers or Clactonian notches and denticulates (layer 17, n 318 tools, 52\% scrapers, 32\% notches/ denticulates; layer 20, n1260 tools, 13\% scrapers, 78.5\% notches/ denticulates; differences are statistically highly significant $\mathrm{chi}^{2}$ 127.219; $\left.\mathrm{p}<0.001\right)$. This variability is directly connected to the inherent flexibility of thick, asymmetric Quina-type flakes that are not only easily adapted to fulfil different functional requirements but also produced as part of an identical production system incorporating the same technical elements. These layers document equivalent technological behaviours geared around different functional objectives. By effectively effacing certain divisions between two industries, the identification of this technological coherenceraises questions concerning theinterpretation of differencesbetweenlithictechno-complexesorBordes' Mousterian variants ("Quina" vs. "Denticulate").

3.3. A Complicated end for the Combe-Grenal sequence (layers 16-1): variable industries with somewhat unclear technological transitions?

While the succession of primary flaking strategies discussed above is fairly clear for layers 37 through 17 , the situation in the final part of the sequence is more problematic. Despite the final four layers containing an extremely limited number of lithic artefacts ( $\mathrm{n}^{1} \mathbf{2} 44,114,144$, and 99), the presence of several bifaces and associated waste products (Bordes, 1972; Pelegrin, 1990; Soressi, 2002; this study) have, not surprisingly, led to their being attributed to the "Mousterian of Acheulean Tradition". Artefact counts correspond to the number of pieces currently found in the boxes labelled levels 1-4 housed at the Musee national de prehistiore, Les-Eyzies-de-Tayac Conversely, the absence of any clear typological or technological markers combined with the relatively small 


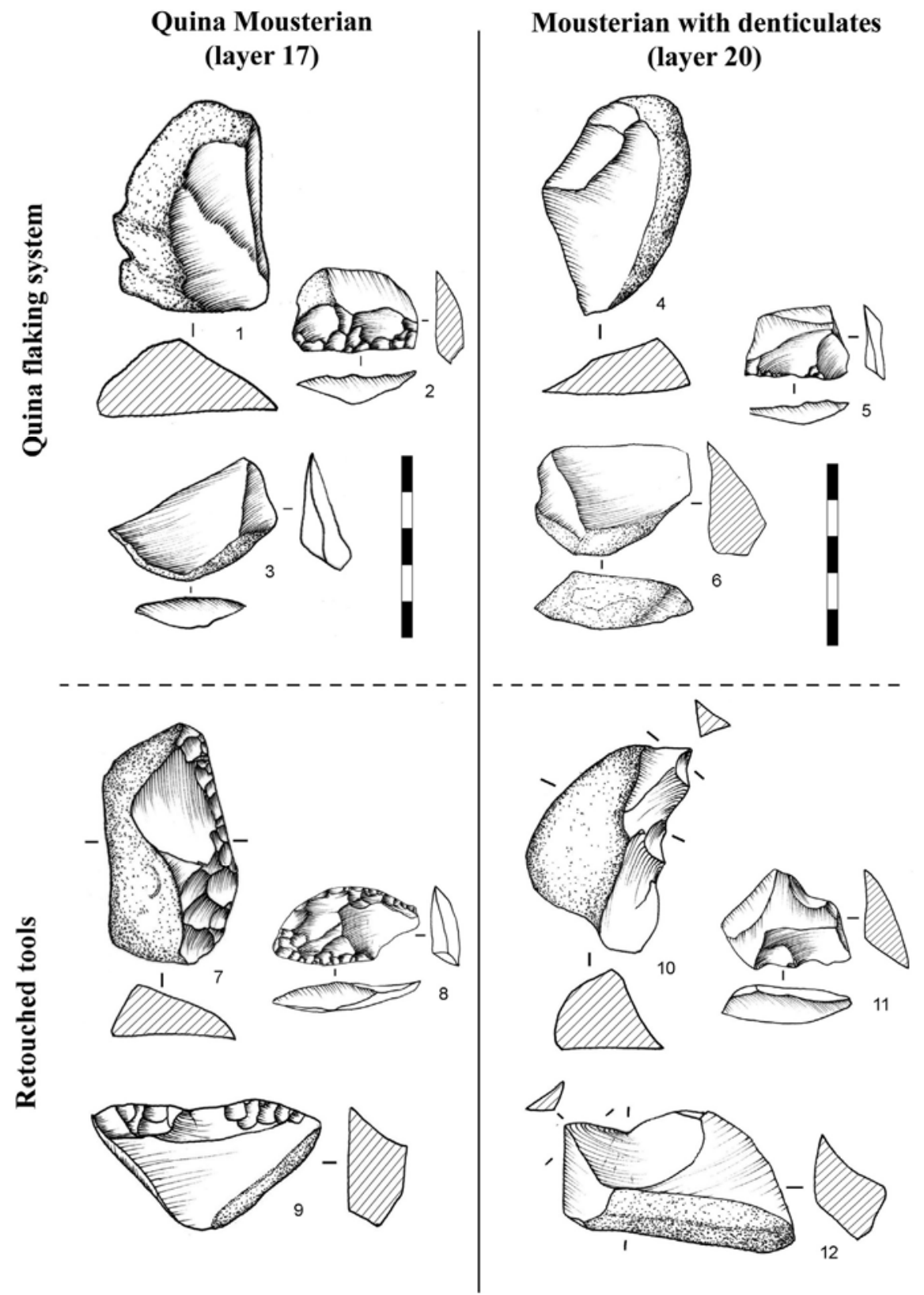

Fig. 4. Comparison of industries based on a Quina production system attributed to the "Quina Mousterian" (layer 17) and "Denticulate Mousterian" (layer 20). 1-6: asymmetrical flakes with cortical back or thick platforms; 7-9: scrapers made on asymmetrical flakes (as described in text); 10-12: Clactonian notches on asymmetrical flakes (as described in text).

size of the assemblages from layers 5 through 10 undoubtedly contributed to their attribution to the "Typical Mousterian". Finally, the more consequential layers 11-16 were all characterised as "Denticulate Mousterian" by Bordes (1972). When viewed in terms of primary flaking strategies, by far the most important aspect of this portion of the sequence is the predominance of the Discoid method associated with notches and denticulates in layers 15 through 11 (Bourguignon and Turq, 2003; Thiébaut, 2005; Faivre, 2011, Fig. 5). Although Discoid and Levallois methods coexist in layers 16, 10-8, and 6-2, the small size of the assemblages precludes any certainty regarding the relative importance of either. Interestingly, the Levallois method is most prevalent in the scraperrich layer 7.

In light of the questions raised by Dibble et al. (2009) concerning the stratigraphic integrity of some of the Combe-Grenal layers, it is entirely possible that the elevated presence of Levallois products in layer 6 may be due in part to their introduction from the immediately underlying Levallois-rich layer 7 via either errors in the field, post-excavation mixing or re-attribution. For instance, Dibble et al. (2009) note that the three-dimensional plotting of nearly $15 \%$ of the objects assigned to layer 11 during excavations are incompatible with their assignment to this layer. Similarly, layer 16, which presents a stark technological departure from the underlying Quina layers given a mix of Discoid and Levallois elements and the anecdotal presence of blade/ bladelet production (Faivre, 2012), may also have suffered some form of excavation bias. Forinstance, is thehigh proportion of denticulates in layer 16 a product of Bordes' excavation methodology (successive horizontal décapages), whereby objects were incorporated from the overlying denticulate-rich layer 15 assigned to the 

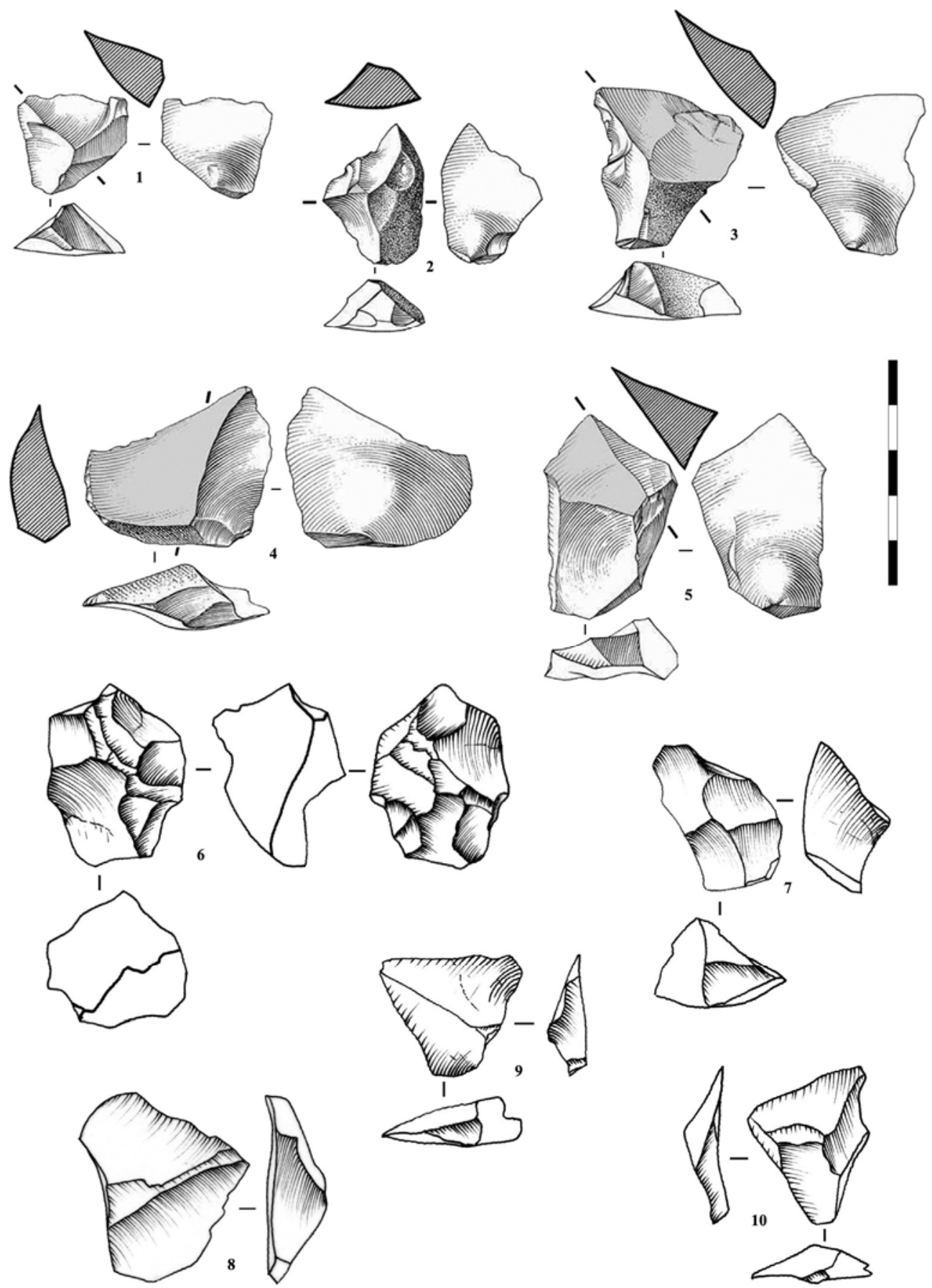

Fig. 5. Examples of Discoid products from layers 14 (1-5) and 12 (6-10): Kombewa-type pseudo-Levallois points (1-5) and pseudo-Levallois points (7-10), bifacial Discoid core (6) (after Bourguignon and Turq, 2003; Faivre, 2008)

“Denticulate Mousterian” (Bordes, 1972; Thiébaut, 2005) during fieldwork? The possible problems identified above combined with the likely event of some post-depositional mixing at the interface of each layer may go some way in explaining the variability of the thinner, less dense final layers and our inability to distinguish similarly clear patterning in primary flaking strategies. In comparison, the richer Quina and Levallois episodes (see above) were excavated over a larger area and portray substantial temporal stability in terms of technology.

In sum, while the final portion of the Combe-Grenal sequence presents what on the surface appears to be fairly straightforward typological succession, the relatively small size of the assemblages leaves open some uncertainty. This is particularly the case with layers 1-4 assigned to the "MTA", which, for the moment, is the one of the only known examples of this type of industry overlying the Discoid-Denticulate Mousterian in south-western France (J aubert et al., 2011). The near exclusive presence of Discoid products (Table 4) in layer 1does, however, question its attribution to the "MTA-B". What is nevertheless clear is that from layer 16 onwards, the Discoid method appears with varying intensity, becoming the exclusive or dominant primary flakingstrategy in layers 15through 11 and in layer 1 
Table 4

Retouched tool and blank counts for the "MTA-B" (layer 1).

\begin{tabular}{llr}
\hline & Type & $\mathrm{Nb}$ \\
\hline Core & Levallois & $\mathbf{1}$ \\
& Discoid & 7 \\
& multi-directional & $\mathbf{1}$ \\
& non-Levallois recurrent centripetal & $\mathbf{1}$ \\
Flake & indeterminate & $\mathbf{1}$ \\
& primary flake and cortical flake $>50 \%$ & 38 \\
& cortical flake<50\% & 43 \\
& Levallois & 1 \\
& typical pseudo-Levallois point & 17 \\
& atypical pseudo-Levallois point & 26 \\
& eclat debordant s.l & 32 \\
& non-Levallois centripetal flake & 15 \\
& elongated flake & 1 \\
& Kombewa-type & 4 \\
Waste & sharpening/resharpening flake & 11 \\
Biface & non-diagnostic flake & 26 \\
Retouched tool & & 23 \\
& & 2 \\
& single side scraper & 1 \\
Total & atypical back knife & 7 \\
& denticulate & 3 \\
& notch & 4 \\
& & 250 \\
\hline
\end{tabular}

3.4. The chronological succession of primary flaking strategies at Combe-Grenal

Based on the above, the upper part of the Combe-Grenal sequence demonstrates an archaeo-stratigraphic organisation (Fig. 6), where a succession of Levallois, Quina, and ultimately Discoid debitage systems is readily apparent. Each can appear in equal measure (Levallois and Discoid) or come to be the dominant (Levallois or Discoid) or exclusive (Quina or Discoid) primary flaking system. Interestingly, our technological approach succeeded in identifying a clear stratigraphic succession where strictly typological approaches had previously failed (Fig. 6). While the "Quina Mousterian" from layers 17 through 26 at Combe-Grenal provides evidence for the emergence of an independent debitage system (Quina flaking system), assemblages attributed to the "Typical" (layers 28-31 and 36-37) and "Ferrassie Mousterian" (layers 27 and 32-25) both record the use of the Levallois system. Unlike the exclusive character of the Quina debitage system, the Levallois method, although always dominant, can coexist with other debitage systems (Discoid, laminar, "bladelet"; Faivre, 2011, 2012). Finally, the Levallois system in the lower layers is more important both in qualitative and quantitative compared to the post-Quina layers, where the Discoid system comes to dominate.

\section{Discussion}

\subsection{Regional comparison: is the Combe-Grenal sequence an} exception?

The Mousterian sequence recorded by F. Bordes at CombeGrenal provides clear evidence for the temporal structure of the major Late Middle Palaeolithic production systems in southwestern France (Delagnes and Meignen, 2006; J aubert, 2008; Delagnes and Rendu, 2011; Discamps et al., 2011; Faivre, 2011). This stratigraphic distribution to some extent parallels Mellars' (1988, 1992, 1996) observations concerning technological change in the same region, notably the chrono-stratigraphic separation and superimposition of Bordes' "Ferrassie", "Quina", and "MTA" variants. Although accounting for the place of the "Typical" or "Denticulate Mousterian" in this linear conception of technological

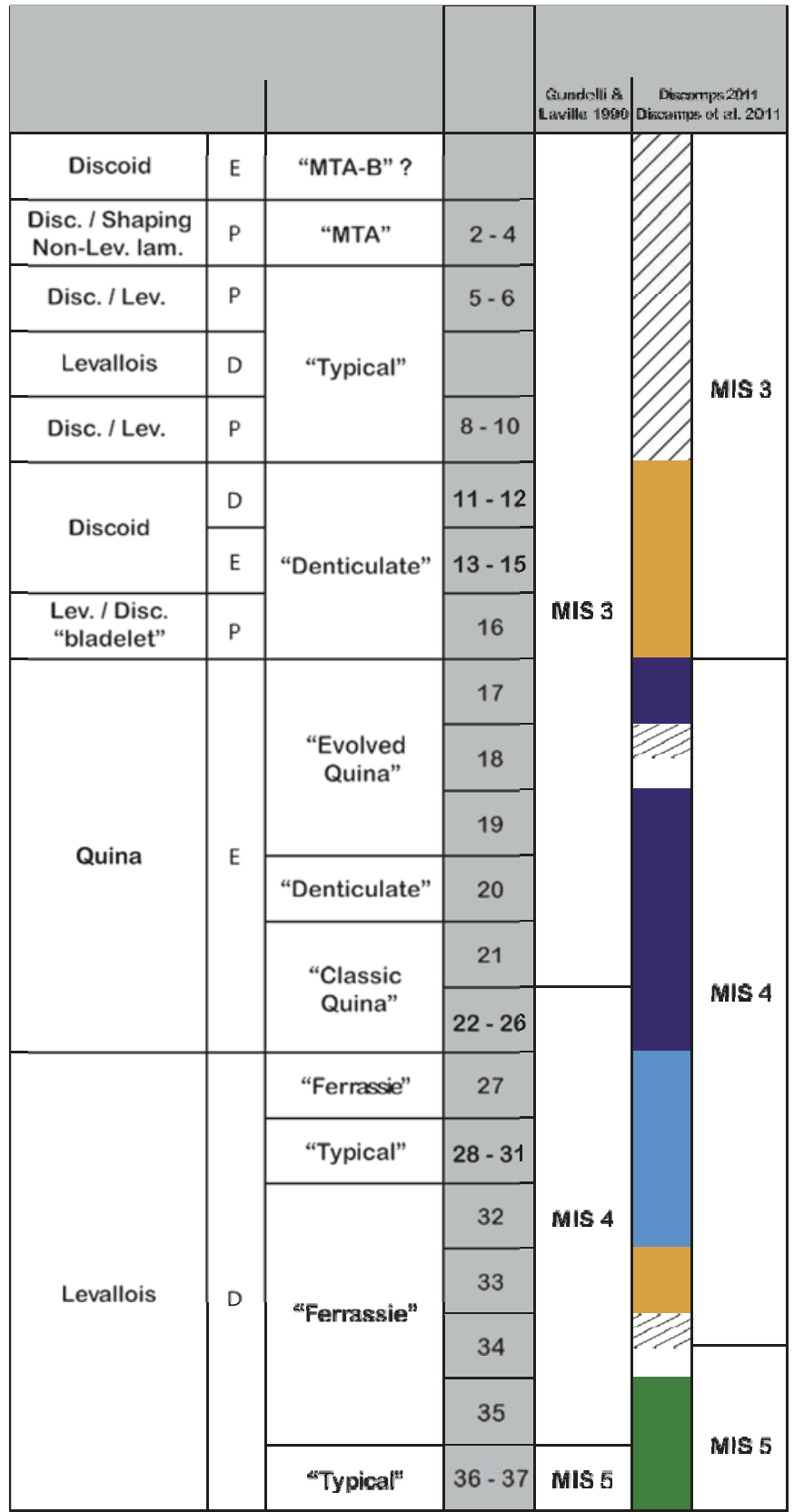

Color codes for dominant ungulates in archaeofaunas

Reindeer $\square$ Red \& Roe Deer $\square$ Bison \& Horse
Reindeer \& Red Deer

\begin{tabular}{|l|} 
Importance of production system \\
\hline E Exclusive $\quad \mathrm{D}$ Dominant $\quad \mathrm{P}$ Present \\
\hline
\end{tabular}

Fig. 6. Summary of the two chronological models proposed for the Combe-Grenal sequence based on faunal analyses. From left to right: 1) Technological system and its importance in each layer (e.g. exclusive), 2) Mousterian typological variants, 3) Combe-Grenal layers, 4) MIS attributions (after Guadelli and Laville, 1990), 5) Revised MIS attributions with the dominant fauna and code for the corresponding ungulate assemblage-zones (UAZ), as defined for south-western France (after Discamps, 2011, in press; Discamps et al., 2011).

evolution still remains its major stumbling block, to its credit Mellars' (1992, 1996) chronological model does mobilise technotypological characteristics deemed specific to the "Ferrassie", "Quina", and "MTA" facies (e.g. presence/absence of the Levallois method, bifacial shaping, Quina retouch, etc.). 
In recentyears, this regional model has been taken up anewand further elaborated using a techno-typological approach incorporating more precisely described lithic techno-complexes in comparison to Bordes' original industrial taxonomy (J aubert, 2008, 2012, 2013; Discamps etal., 2011; J aubert et al., 2011, Table 5). This revised archaeological succession incorporating new data from lithic technology undoubtedly represents an important step in our understanding of the Middle Palaeolithic of south-western France. With that said, the structure of this new model largely employs the sametypologicalinformation and taxonomyinheritedfromBordes, leaving thequestion of which forms of data should begiven priority largely unanswered. For example, on what basis can a "Quina Mousterian" with denticulates be distinguished from a "DenticulateMousterian" with a Quinaflakingsystem(Faivre, 2009-10), ora scraper-rich "Typical Mousterian" with Levallois debitage from a "Ferrassie Mousterian"?

Table 5

Bordes' Mousterian facies compared with the diversity of regional lithic technocomplex (LTC) in south-western France identified by J aubert (2012).

\begin{tabular}{|c|c|}
\hline $\begin{array}{l}\text { Mousterian facies } \\
\text { (Bordes, 1953, 1981) }\end{array}$ & Lithic techno-complexes (J aubert 2012) \\
\hline MTA A & $\begin{array}{l}\text { Recurrent Levallois, bifaces } \\
\text { Successive crossed-unipolar Levallois/ Discoid, bifaces } \\
\text { Elongated flakes/Laminar/ Discoid,bifaces }\end{array}$ \\
\hline MTA B & $\begin{array}{l}\text { Discoid with elongated flakes } \\
\text { Discoid with elongated flakes and bifaces } \\
\text { Discoid/Levallois with elongated flakes } \\
\text { Uni/bipolar \& centripetal Levallois with backed knives }\end{array}$ \\
\hline Quina & $\begin{array}{l}\text { Quina } \\
\text { Quina with denticulates }\end{array}$ \\
\hline Ferrassie & $\begin{array}{l}\text { Levallois with large scrapers } \\
\text { Centripetal Levallois } \\
\text { Centripetal \& unipolar Levallois } \\
\text { Levallois/ Discoid }\end{array}$ \\
\hline Typical & $\begin{array}{l}\text { Centripetal \& Unipolar Levallois } \\
\text { Levallois/ Kombewa } \\
\text { Levallois dominant/ Discoid } \\
\text { Levallois cf. Asinipodian }\end{array}$ \\
\hline Denticulate & $\begin{array}{l}\text { Discoid, denticulates } \\
\text { Centripetal \& Unipolar Levallois with denticulates } \\
\text { Quina with denticulates } \\
\text { Levallois dominant/ Discoid with denticulates } \\
\text { Discoid dominant/ Levallois with denticulates }\end{array}$ \\
\hline
\end{tabular}

This conundrum effectively evokes the same issues high- lighted above concerning the use of ill-defined and ambiguous industrial denominations in techno-typological approaches. The separation of Mousterian industries into discrete lithic techno- complexes still appears somewhat insufficiently substantiated in the sense that the criteria deemed apt for their definition or differentiation remain imprecise. Consequently, a reliance exclusively on quantitative data concerning retouched tool frequencies (typology), production methods (technology), raw material economy, or tool reduction models produce discordant and sometimes contradictory results. The amalgamation of these different processes and contingencies operating at different spatio-temporal scales probably goes some way in explaining differences between particular industries, and, in our opinion, the chronology of each of these doubtlessly interrelated aspects requires independent evaluation before any genuine temporal (or not) trends can be distinguished.

Although such an imposing project is still in its early stages, the results presented here do, however, allow the chronological dimension of lithic production systems to be addressed in more detail. Moreover, the succession of Mousterian technological systems identified at Combe-Grenal is not an exception in southwestern France. The same temporal organisation has been fully - or at least partially - documented in several other regional archaeosequences (Delagnes and Meignen, 2006; J aubert, 2008,

2013; Delagnes and Rendu, 2011): La Quina, Jonzac, and Hauteroche in the Charentes, Roc-de-Marsal, Pech de l'Azé IV, La Rochette, Abri Chadourne in the Dordogne, and La Rouquette in the Tarn.

\subsection{The chronological position of the Combe-Grenal sequence}

The numerical chronology of the Middle Palaeolithic in southwestern France today benefits from a substantial corpus of radiometric dates (see Guibert et al., 2008 for a synthesis; Guérin et al., 2012; McPherron et al., 2012; Richter et al., 2013a, 2013b for the most recent dates). With that said, the reliability of the numerical dates produced by Bowman and Sieveking (1983) for CombeGrenal have recently been severely questioned by Guibert et al. (2008) citing certain methodological shortcomings. Pending new numerical dates, correlating the Combe-Grenal sequence with other regional sequences and climatic events must rely on other arguments.

Based on bio-stratigraphic and geo-archaeological data available at the time, Guadelli and Laville (1990) proposed that the upper terrace layers extended from MIS 5 to 3, or between broadly 75 and $40 \mathrm{ka}$. More recently, faunal data from the Combe-Grenal sequence was integrated in a regional synthesis of Middle Palaeolithic archaeo-faunas (Discamps et al., 2011). Correlating changes in the structure of regional faunal communities with independent, high-resolution palaeo-environmental data (marine core MD042845 in the Golf of Gascogne) was made possible by comparing all available stratigraphic and faunal data (from both anthropic and natural accumulations), as well as numerical dates, within the same analytical framework (Discamps, 2011; Discamps et al., 2011). This new regional archaeo-sequence allowed several Mousterian sequences to be placed within a numerical chronology, which was subsequently partly confirmed by a combination of faunal data and recently obtained radiometric dates (Guérin et al., 2012).

The revised chronology for the Combe-Grenal sequence (Discamps, 2011; Discamps et al., 2011) only differs slightly from that originally proposed by Guadelli and Laville (op. cit., cf. Fig. 6). In both models, Levallois dominated assemblages occupy the end of MIS 5 and beginning of MIS 4 (layers 37-27 of CombeGrenal), a pattern reinforced by new radiometric dates obtained for Roc-de-Marsal (Guérin et al., 2012) and Pech de l'Azé IV (Richter et al., 2013). While Guadelli and Laville (1990) considered the 'classic' "Quina Mousterian" occupations to fall within MIS 4 and the 'evolved' variant in MIS 3, recent work tends to place the entirety of the Quina system in MIS 4 (Combe-Grenal layers 26-17). Unfortunately, numerical dates for Quina occurrences remain rare, a problem probably tied to the scarcity of burnt flint in these layers. However, recently obtained dates are nevertheless compatible with an MIS 4 age for the "Quina Mousterian", as at J onzac (Richter et al., 2013b) and Les Pradelles (Vieillevigne and Guibert, 2007; Maureille, 2010). Both models place the uppermost part of the Combe-Grenal sequence (layers 161) in MIS 3.

\subsection{The question of Mousterian variability}

Centring analyses away from Bordes' typologically focused taxonomic system towards more holistic technological approaches clearly generates a new perception of Mousterian variability and the mechanisms underlying it. Moreover, research focused on 
lithic production systems today allows for a better understanding of not only the succession and organisation of technical knowhow, but patterns of techno-economic behaviour identified from the same context, which, in this case, spans a considerable period of time.

The question remains how to interpret the internal technoeconomic variations of the different chronologically organised lithic production systems. This difficulty, in our opinion, harks back to questions concerning the impact of technology in models for the organisation of prehistoric groups and, more specifically, huntergatherer mobility strategies (e.g. Binford, 1979; Kelly, 1983, 1988; Bamforth, 1986; Kuhn, 1992, 1995; Andrefsky, 2009). In the context of south-western France, Neandertal mobility patterns have been approached by focusing on the inherent interrelation between lithic production and the dynamics of human movements taking into account, for instance, the transfer and spatio-temporal fragmentation of chaînes opératoires for certain raw materials or tools (Geneste, 1988, 1990, 1991; Turq, 2000; Turq et al., 2013) and the emergence of particular production systems in relation to group mobility patterns and different hunting strategies (Delagnes and Rendu, 2011).

In the case of Combe-Grenal, the comparison of technological data with information relative to raw material provisioning strategies and elements of subsistence strategies reveals interesting correspondences between lithic techno-complexes and patterns of landscape use. The Combe-Grenal sequences records substantial environmental changes during the period between MIS 5 and 3, changes readily perceptible in the faunal signal (Guadelli, 1987, 2011) and which very likely elicited significant fluctuations in available ungulate biomass (Discamps, 2011, in press). It would be expected that theseenvironmental shifts had non-negligibleeffects on Neandertal behaviour and demography, including choices related to tool and or site function, subsistence strategies, and resource management. However, the Combe-Grenal sequence demonstrates that despitetheamplitudeand occasional rapidity of these environmental changes, they did not necessarily impact technology to any great extent. For instance, while reindeer dominate the Quina assemblages (layers 17-26), they also do in certain layers where the Levallois method prevails (layers 27-31). Interestingly, although in layer 20 reindeer gives way to horse, bovids, and deer, the lithic technology remains essentially unchanged - a techno-economic variant of the Quina production system.

Given the importance of the Combe-Grenal sequence for the Mousterian in south-western France, numerous researchers have attempted to mobilise the site's faunal assemblages to address questions related to, amongst others, subsistence strategies, symbolic manifestations, or organic tool industries (e.g. Chase, 1983, 1986, 2001; Vincent, 1993; Steele, 1999; Chase, 2001; Fernandez et al., 2006). Despite the important role of zooarchaeological data in reconstructing subsistence strategies or discussing site function, the Combe-Grenal faunal material should be interpreted with extreme caution (Guadelli, 1987, 2011). In addition to the probable curation problems highlighted by Dibble et al. (2009) concerning the lithic objects, F. Bordes himself considered that the recovery method used during his excavations certainly introduced major biases and inconsistencies in the representation of the skeletal material (Guadelli, 2011:202), a well-known problem for early excavations (e.g. Marean and Kim, 1998). Unfortunately, the zooarchaeological information currently available for the CombeGrenal sequence is therefore extremely limited and of dubious analytical value. These biases are, however, of greater concern for zooarchaeological analyses (e.g., interpreting skeletal profiles) than for environmental inferences based on the abundance of macromammals (as in Fig. 6).
Raw material exploitation patterns also remain more or less the same between the Quina and Levallois production systems; both incorporate non-local sources $(0-50 \mathrm{~km}$; e.g. Bergeracois and Fumelois flint; Fig. 7) demonstrating an expansive provisioning territory. As already discussed above, internal variations evident with the Levallois system seem to result from a greater incidence of blank transformation for the "Ferrassie Mousterian" and a greater proportion of unmodified blanks for the "Typical Mousterian". These differences also seem to expose a contrast in tool use-lives: longer episodes for the "Ferrassie" (more heavily reduced retouched tools) and shorter for the "Typical". Recalling aspects of curated versus expedient tools (Binford, 1979), transport and reduction factors do not coincide with the long distance transfer of unmodified blanks or retouched pieces (e.g. 2.6\% for the"Typical Mousterian" layers 20-30 versus 2.8\% for the "Ferrassie Mousterian" in layer 27).

Departing from the pattern seen with the Levallois and Quina systems, the Discoid assemblages indicate a reduction in the raw material provisioning territory. This more local provisioning strategy, which becomes the trend throughout MIS 3 in the region Faivre et al. 2013, could reflect occupations oriented around the exploitation of resources directly available in the vicinity of the site. As seen with other well-documented Discoid contexts, these activities often take on a more specialised character connected to the specific function of typical Discoid products (e.g., butchery and carcass processing; J aubert et al., 1990; Brugal, 1999; Coumont, 2005). These differences also undoubtedly portray a diversity of objectives tied in some way or another to site function. The influence of functional choices is also relevant for the assemblages from the end of the Combe-Grenal sequence (MIS 3), where the Discoid system is dominant. Notches and denticulates are either heavily represented ("Typical Mousterian") or nearly exclusive ("Denticulate Mousterian") in several other MIS 3 Discoid assemblages in south-western France (Jaubert et al., 1990; Faivre, 2004; Thi'́baut, 2005). Unfortunately, the absence of robust zooarchaeological information for the entirety of the Combe-Grenal sequence precludes a more detailed discussion of the site's changing function.

\section{Conclusion}

Environmental fluctuations over the course of the last glaciation had a major and direct impact on the manner in which available resources were exploited by Neandertal groups and how they organised themselves techno-economically. Our technological analysis identified clear temporal trends in lithic production systems across the Combe-Grenal sequence, whose variability is an expression of differing functional and economic choices. While a clear succession of production systems (Levallois, Quina, and ultimately Discoid) is evident in the uppermost terrace, a more detailed taphonomic analysis of the archaeostratigraphy is necessary to investigate both the internal variations of each episode and whether shifts between production systems occur in a context of techno-economic continuity or rupture. Moreover, it is plainly clear from the foregoing that the heuristic potential of comparing faunal data and raw material provisioning strategies with temporal patterns in technoeconomic behaviour undoubtedly warrants further attention and elaboration. Currently, this type of approach is extremely limited, due primarily to problems linked to the recovery and curation of the Combe-Grenal material. New multidisciplinary fieldwork incorporating a comprehensive numerical dating program is underway in order to not only address exactly these issues but gather new data from one of the most important Mousterian sequences in south-western France. 

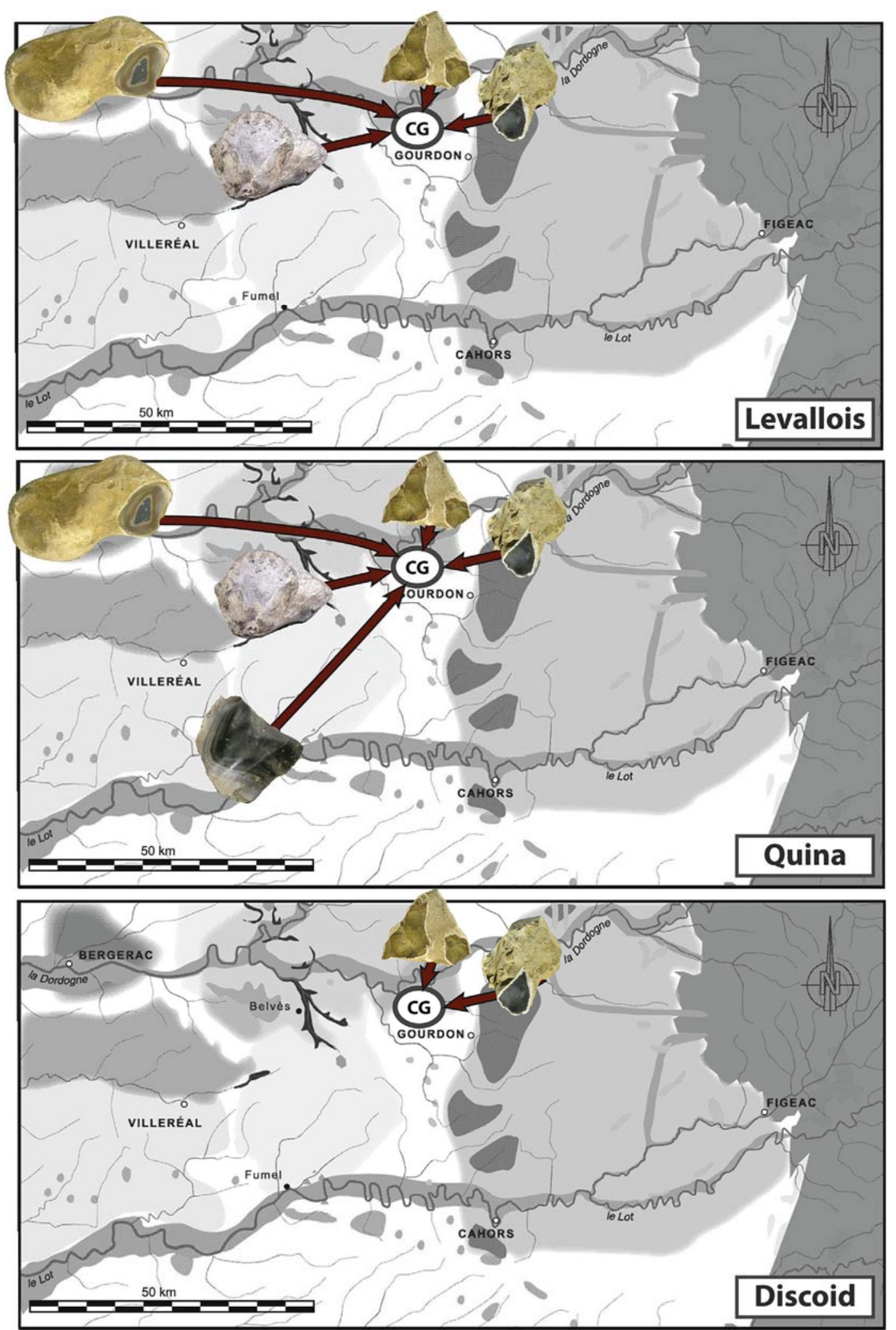

Bergeracois flint (Maastrichtian)

Belvès flint (Campanian)

Fumélois flint (Turonian)

Blond flint

(Coniacian and Santonian)

Grey and black flint

(Coniacian and Santonian)

Fig. 7. Raw material provisioning territories for Combe-Grenal as a function of lithic production systems (layers $31-27$ for the Levallois system, $26-17$ for the Quina system, and $12-15$ for the Discoid system). 


\section{Acknowledgments}

This research was carried out thanks to a grant from the French National Research Agency program Investissements d'avenir (ANR-

10-LABX-52) to the NéMo project - Neeandertal face à la mort: Cultures/ Pratiques funeraires directed by J .-Ph. Faivre, Ch. Lahaye, and B. Maureille. We would like to thank the UMR-5199 PACEA, UMR-5060 CRP2A-IRAMAT, the French Ministry of Culture (MCC), the Aquitaine Regional Archaeology Service for granting access to archival material concerning François Bordes' work at CombeGrenal, and the Musee National de Préhistoire, Les Eyzies (dir. Cleyet-Merle). We are also grateful to Jean-Philippe Rigaud for discussions concerning excavations at Combe-Grenal and to Sylvain Soriano as well as three anonymous reviewers for constructive comments.

\section{References}

Anderson-Gerfaud, P. 1981 Contribution méthodologique à l'analyse des microtraces d'utilisation sur des outils préhistoriques. Ph.D. thesis. Universite de traces d'utilisation

Andrefsky Jr., 2009. The analysis of stone tool procurement, production, and maintenance. J ournal of Archaeological Research 17, 65-103.

Ashton, N.-M., Cook, J., Lewis, S.-G., Rose, J., 1992. High Lodge: Excavations by G. de G. Sieveking 1962-68 and Cook J 1988. British Museum Press, London. Bamforth,

D.B., 1986. Technological efficiency and tool curation. AmericanAntiquity 51, 3-20.

Beyries, S., Walter, P., 1996. Racloirs et colorants à Combe-Grenal: le problème de la retouche Quina. In: Bietti, S., Grimaldi, S. (Eds.), Reduction Processes for the European Mousterian. Actes du colloque international de Rome. Quaternaria Nova vol. 6, 167-185.

Binford, L.-R., Binford, S.-R., 1966. A preliminary analysis of functional variability in the Mousterian of Levallois facies. American Anthropologist 68, 238-295.

Binford, L.-R., Binford, S.-R., 1969. Stone tools and human behavior. Scientific American 220, 70-84.

Binford, L.-R., 1973. Interassemblage variability: the Mousterian and the "functional" argument. In: Renfrew, C. (Ed.), The Explanation of Culture Change Duckworth, London.

Binford, L.-R., 1977. Forty-seven trips: a case study in the character of archaeologica formation processes. In: Wright, R.V.S. (Ed.), Australian Institute of Aboriginal Studies. Stone Tools as Cultural Markers, Canberra, pp. 24-36.

Binford, L.-R., 1979. Organization and formation processes: looking at curated technology. J ournal of Anthropological Research 35, 255-273.

Boëda, E. 1988. Le concept laminaire: rupture et filiation avec le concept Levallois. In: Otte, M. (Ed.), L'Homme de Nénndertal. Actes du colloque international de Liëge (4-7 December 1986). vol. 4. La mutation. J.K.Kozlowski (dir.) Liëge, ERAUL 35, pp.41-60.

Binford, L.-R., 1989. Isolating the transition to cultural adaptations : an organizational approach. In: Trinkaus, E. (Ed.), The Emergence of Modern Humans: Biocultural Adaptations in the Later Pleistocene. Cambridge University Press, Cambridge, pp. 18-41.

Boëda, E., 1991 La conception trifaciale d'un nouveau mode de taille palélithique. In: Bonifay, E., Vandermeersch, B. (Eds.), Les premiers Européens. Actes du 114th Congrès national des Sociétés savantes (Paris, 3-9 April 1989). C.T.H.S, Paris, pp. 251-263.

Boëda, E., 1993. Le débitage discoïde et le débitage Levallois récurrent centripète. Bulletin de la Sociéé Próhistorique Française 90, 392-404

Boëda, E., with the collaboration of, Kervazo, B., Mercier, N., Valladas, H., 1996. Barbas C3 base (Dordogne). Une industrie bifaciale contemporaine des industries du Moustérien ancien: une variabilité attendue. In: Bietti, A., Grimaldi, S. (Eds.), Reduction Processes for the European Mousterian. Actes du colloque international de Rome. Quaternaria Nova vol. 6, 465-504.

Boëda, E., 1997. Technogenèse de systèmes de production lithique au Paléolithique inferieur et moyen en Europe Occidentale et au Proche-Orient. Habilitation à
Diriger des Recherches, vol. 2. Université de Paris X-Nanterre, 173 pp., 87 fig.

Boëda, E., Pelegrin, J., 1983. Approche technologique du nucléus Levallois à éclat. Etudes préhistoriques 1979-1980 15, 41-48 (published in 1983).

Boëda, E., Geneste, J.-M., Meignen, L., 1990. Identification de chaînes opératoires lithiques du Paléolithique ancien et moyen. Palé 2, 43-80.

Bordes, F., 1953. Essai de classification des industries “moustériennes”. Bulletin de la SociétéPrühistorique Française 50, 457-466.

Bordes, F., 1955. La stratigraphie de la grotte de Combe-Grenal (Dordogne): note préiminaire. Bulletin de la SociétéPréhistorique Française 52, 426-429.

Bordes, F., 1961 Typologie du Paléolithique inférieur et moyen. In: Mémoire 1, 2 vol. Publications de l'Institut de Préhistoire de l'Université de Bordeaux, Delmas, Bordeaux.

Bordes, F., 1972. A Tale of Two Caves. Harper and Row Publishers, New York.

Bordes, F., 1981 Vingt-cinq ans après: le complexe moustérien revisité Bulletin de la Sociétépréhistorique française 78, 77-87.
Bordes, F., Bourgon, M., 1951 Le complexe moustérien: Moustérien, Levalloisien et Tayacien. L'Anthropologie 55, 1-23.

Bourguignon, L., 1996. La conception de débitage Quina. In: Bietti, A., Grimaldi, S. (Eds.), Reduction Processes for the European Mousterian. Actes du colloque international de Rome. Quaternaria Nova 6, 149-166.

Bourguignon, L., 1997. Le Moustérien de type Quina : nouvelle définition d'une technique. These de doctorat. Universite de Paris X-Nanterre, 2 tomes, $672 \mathrm{pp}$. Bourguignon, L., Turq, A., 2003. Une chaîne opératoire de débitage sur éclat du Moustérien à denticulés aquitain: les exemples de Champs de Bossuet et de Combe-Grenal c.14. In: Peresani, M. (Ed.), Discoïd Lithic Technology. Advances and Implications, BAR International. Series 1120. Archeopress, Oxford, pp. 131-152.

Bourguignon, L., Faivre, J.-Ph., Turq, A., 2004. Ramification des chaînes opératoires : une spécificitédu Moustérien? Paléo 16, 37-48.

Bowman, S.G.E., Sieveking, G., 1983. Thermoluminescencedating of burnt flint from Combe Grenal. Pact 9, 253-268.

Brugal, J.-Ph, 1999. Etude de populations des grands bovidés européens : intérêt pour la connaissance des comportements humains au Paléolithique. In: Brugal, J .-Ph, David, F., Enloe, J .-G., J aubert, J . (Eds.), Le Bison: gibier et moyen de subsistence des hommes du Paléolithique aux paléoindiens des grandes plaines. Ed. APDCA, Antibes, pp. 85-104

Chase, P.G., 1983. The Use of Animal Resources in the Mousterian of Combe-Grenal, France (Ph.D. thesis). University of Arizona, USA.

Chase, P.G., 1986. The hunters of Combe-Grenal. Approaches to Middle Paleolithic Subsistence in Europe. In: BAR International Series. Archeopress, Oxford.

Chase, P.G., 2001. Punctured reindeer phalanges from the Mousterian of Combe Grenal (France). Arheoloski vestnik 52, 17-23.

Chevrier, B., 2006. De l'Acheuléen méridional au technocomplexe trifacial: la face cachée des industries du Bergeracois. Apport de l'analyse technologique de l'industrie lithique de Barbas I C4 sup (Creysse, Dordogne). Gallia préhistoire 48, 207-252.

Coumont, M.-P., 2005. Taphonomie préhistorique: mammiferes fossils en contexte naturel, les avens pieges, apports pour l'eude des archéfaunes (Ph.D. thesis) naturel, les avens pieges, apports
UniversitéAix-Marseille 1, France.

Delagnes, A., 1992. L'organisation de la production lithique au Palélithique moyen. Approche technologique à partir de l'éude des industries de la Chaise-deVouthon (Charente) (Ph.D. thesis). Universitéde Paris X- Nanterre, France.

Delagnes, A., Meignen, L., 2006. Diversity of lithic production systems during the Middle Paleolithic in France: are there any chronological trends? In: Hovers, E., Kuhn, S. (Eds.), Transitions before the Transition: Evolution and Stability in the Middle Paleolithic and Middle Stone Age. Springer, Santa Barbara, CA, pp. 85-107.

Delagnes, A., Rendu, W., 2011 Shifts in Neandertal mobility, technology and subsistence strategies in western France. J ournal of Archaeological Science 38 1771-1783.

Dibble, H.L., 1984. Interpreting typological variation of Middle Paleolithic scrapers: function, style, or sequence of reduction? J ournal of Field Archaeology 11, 431436.

Dibble, H.L., 1987. Reduction sequences in the manufacture of Mousterian implements of France. In: Soffer, O. (Ed.), The Pleistocene of the Old World. Regional Perspectives Plenum., New York, pp. 33-45.

Dibble, H.L., 1995. Middle Paleolithic scraper reduction: background, clarification, and review of evidence to data. J ournal of Archaeological Method and Theory 2, 299-368.

Dibble, H.L., 1995. Raw Material Availability, Intensity of Utilization, and Middle Paleolithic Assemblage Variability. In: Dibble, H.L., Lenoir, M. (Eds.) The Middle Paleolithic Site of Combe-capelle Bas (France). University of Pennsylvania, University Museum Monographs $\mathrm{n}^{\circ}$ 91, Philadelphia, pp. 289-316.

Dibble H.L Rolland, N., 1992. On assemblage variability in the Middle Palaeolithic of Western Europe : history, perspectives and a new synthesis. In: Dibble, H.L. Mellars, P.-A. (Eds.), The Middle Palaeolithic: Adaptation, Behavior, and Variability. University of Pennsylvania, University Museum Monographs $\mathrm{n}^{\circ} 72$, Philadelphia, pp. 1-28.

Dibble, H.L., Bar-Yosef, O., 1995. The Definition and Interpretation of Levallois Technology. Prehistory Press, Madison.

Dibble, H.L., McPherron, S.P., Dennis Sandgathe, S., Goldberg, P., Turq, A., Michel Lenoir, M., 2009. Context, curation, and bias: an evaluation of the Middle Paleolithic collections of Combe-Grenal (France). J ournal of Archaeological Science 36, 2540-2550.

Discamps, E., 2011 Hommes et hyènes face aux recompositions des communauté d'Ongulés (MIS 5-3): ééments pour un cadre paléoécologique des sociétés du Palélithique moyen et supérieur ancien d'Europe de l'Ouest (Ph.D thesis). Universitéde Bordeaux 1, France.

Discamps, E., 2013. Ungulate biomass fluctuations endured by Middle and Early Upper Paleolithic societies (SW France, MIS 5-3): the contributions of modern analogs and cave hyena paleodemography. Quaternary International (in press), accessible online.

Discamps, E., Jaubert, J., Bachellerie, F., 2011. Human choices and environmental constraints: deciphering the variability of large game procurement from Mousterian to Aurignacian times (MIS 5-3) in southwestern France. Quaternary Science Reviews 30, 2755-2775.

Faivre, J.-Ph, 2004. L'industrie lithique moustérienne du niveau G7 des Fieux (Miers, Lot): des matériaux, des schémas opératoires, un même objectif. Paléo 16, 7190. 
Faivre, J.-Ph., 2008. Thèse de doctorat. Organisation techno-économique des systèmes de production dans le Paléolithique moyen récent du Nord-est aquitain : Combe-Grenal et Les Fieux, 1 Université Bordeaux, 555pp.

Faivre, J.-Ph, 2009-2010. Le " Moustérien à denticulés » de la couche 20 de CombeGrenal: implications techniques, économiques et fonctionnelles au sein du système de production Quina en Périgord. Paléo 21, 135-162.

Faivre, J.-Ph, 2011 Organisation techno-économique des systèmes de production dans le Paléolithique moyen récent du nord-est aquitain. In: BAR International Series 2280. Archeopress, Oxford.

Faivre, J .- Ph, 2012. A material anecdote but technical reality: bladelet and small blade production during the recent Middle Paleolithic at Combe-Grenal rock shelter. Lithic Technology (1), 5-24.

Faivre, J.-Ph, Turq, A., Bourguignon, L., Bismuth, Th, Colonge, D., Demars, P.-Y., Jarry, M., J aubert, J., 2013. Le Paléolithique moyen du Quercy; comportements techno-économiques et variabilit's des productions lithiques. In: Jarry, M., Brugal, J.-Ph, Ferrier, C. (Eds.), Modalités d'occupations et exploitation des Brugal, J.-Ph, Ferrier, C. (Eds.), Modalites d'occupations et exploitation des
milieux au Paléolithique dans le Sud-Ouest de la France : l'exemple du Quercy milieux au Paleolithique dans le Sud-Ouest de la France : l'exemple du Quercy Actes du Colloque organisedans le cadre du XVIer 2006). Supplement 5, Paléo, 197-235.

Fernandez, Ph, Guadelli, J .-L., Fosse, Ph, 2006. Applying dynamics and comparing life tables for Pleistocene Equidae in anthropic (Bau de l'Aubesier, CombeGrenal) and carnivore (Fouvent) contexts with modern feral horse populations (Akagera, Pryor Mountain). J ournal of Archaeological Science 33, 176-184.

Forestier, H., 1993. Le Clactonien: mise en application d'une nouvelle méthode de débitage s'inscrivant dans la variabilité des systèmes de production lithique du Paleolithique ancien. Palé 5, 53-82.

Geneste, J.-M., 1988. Systèmes d'approvisionnement en matières premières au Paléolithique moyen et au Paléolithique supérieur en Aquitaine. In: Kozlowski, J. (Ed.), L'Homme de Neandertal, La Mutation, vol. 8. ERAUL, Liëge, pp. 61-70.

Geneste, J.-M., 1990. Développement des systèmes de production lithique au cours du Palélithique moyen en Aquitaine septentrionale. In: Farizy, C. (Ed.), loque international de Nemours, 9-11 May 1988, Mémoires du Musé de loque international de Nemours, 9-11
Préhistoire d'Ile-de-France 3, pp. 203-213.

Geneste, J.-M., 1991 Systèmes techniques de productions lithiques: variations techno-économiques dans les processus de rélisation des outillages paléolithiques. Technique et Culture 17-18, 1-36.

Geneste, J.-M., Jaubert, J., Lenoir, M., Meignen, L., Turq, A., 1997. Les moustériens charentiens du Sud-ouest et du Languedoc oriental: approche technologique et variabilitégéographique. Paléo 9, 101-142.

Guadelli, J.-L., 1987. Contribution à l'éude des zoocénoses préhistoriques en Aquitaine (Würm ancien et interstade würmien) (Ph.D. thesis). Université de Bordeaux I, France.

Guadelli, J.-L., 2011 Les associations fauniques de grands mammiferes de la séquence du plástocène supérieur de Combe-Grenal (Dordogne, France) et la biochronologie des OIS 5 à 3. In: 134e congrès du CTHS, Colloque 3.2. François Bordes, Bordeaux, 20-25 April 2009, pp. 199-219.

Guadelli, J.-L., Laville, H., 1990. L'environnement climatique de la fin du Moustérien à Combe-Grenal et à Camiac: confrontation des données naturalistes et implications. In: Farizy, C. (Ed.), Paléolithique Moyen Récent et Paléolithique Supérieur Ancien en Europe, Nemours, Mémoires du Musé de Préhistoire d'Ile de France 3, pp. 43-48.

Guérin, G., Discamps, E., Lahaye, C., Mercier, N., Guibert, P., Turq, A., Dibble, H.L McPherron, S.P., Sandgathe, D., Goldberg, P., Jain, M., Thomsen, K., PatouMathis, M., Castel, J .-C., Soulier, M.-C., 2012. Multi-method (TL and OSL), multimaterial (quartz and flint) dating of the Mousterian site of Roc de Marsal (Dordogne, France): correlating Neanderthal occupations with the climatic variability of MIS 5-3. J ournal of Archaeological Science 39, 3071-3084.

Guibert, P., Bechtel, F., Bourguignon, L., Brenet, M., Couchoud, I., Delagnes, A., Delpech, F., Detrain, L., Duttine, M., Folgado, M., Jaubert, J., Lahaye, Ch, Lenoir, M., Maureille, B., Texier, J.-P., Turq, A., Vieillevigne, E., Villeneuve, G., 2008. Une base de données pour la chronologie du Paléolithique moyen dans le Sud-Ouest de la France. In: J aubert, J., Bordes, J.-G., Ortega, I. (Eds.), Les sociéés
du Paléolithique du grand Sud-Ouest de la France : nouveaux gisements, du Paleolithique du grand Sud-Ouest de la France : nouveaux gisements, Française XLVII, pp. 19-40.

Hiscock, P., Clarkson, C., 2007. Retouched notches at Combe Grenal (France) and the reduction hypothesis. American Antiquity 72, 176-190.

Hiscock, P., Turq, A., Faivre, J .-Ph., Bourguignon, L., 2009. Quina procurement and tool production. In: Blades, B., Adams, B. (Eds.), Lithic Materials and Paléolithic Societies. Blackwell Edition, pp. 232-246.

J aubert, J., 1994. Les industries lithiques. In: Farizy, C., David, F., J aubert, J. (Eds.), Hommes et Bisons au Paléolithique moyen à Mauran (Haute-Garonne), GalliaPríhistoire Supplement. CNRS, pp. 73-167.

J aubert, J., 2008. The Chronostratigraphy of Middle Paleolithic Industries in France: new Data from the Southwest. In: Paleoanthropology Meeting (abstract), Vancouver, Canada.

Jaubert, J., 2012. Les archéo-séquences du Paléolithique moyen du Sud-Ouest de la France: quel bilan un quart de siëcle après François Bordes. CTHS 29, 235-253.

Jaubert, J., 2013. Middle Palaeolithic archeo-sequences from southwestern France: where do we stand a quarter century after Francois Bordes?. In: Basic Issues in Archaeology, Anthropology, and Ethnography of Eurasia, Festschrift on the occasion of Anatoly Derevianko's 70th birthday. Novosibirsk, Institute of Archaeology and Ethnography, SB RAS Press, Novosibirsk, pp. 194-212.

Jaubert, J ., Lorblanchet, M., Laville, H., Slott-Moller, R., Turq, A., Brugal, J-Ph, 1990. Les chasseurs d'Aurochs de La Borde - un site du Palélithique moyen (Livernon, Lot), Paris, MSH, Document d'Archéologie Française ${ }^{\circ} 27$

J aubert, J., Mourre, V., 1996. Coudoulous, Le Rescoundudou, Mauran: diversité des matières premières et variabilité des schémas de production d'élats. In: Beitti, A., Grimaldi, S. (Eds.), Reduction Processes for the European Mousterian, Proceeding of the international Round Table, Rome, May 26-28 1995. Quaternaria Nova vol. 6, 313-341.

J aubert, J., Bordes, J.-G., Discamps, E., Gravina, B., 2011. A new look at the Middle Palaeolithic sequence in southwestern France. In: Derevianko, A., Shunkov, M.V. (Eds.), Characteristic Features of the Middle to Upper Paleolithic Transition. SB RAS Press, Novosibirsk, pp. 102-118.

Kelly, R.L., 1983. Hunter-gatherer mobility strategies. J ournal of Anthropological Research 39, 277-306.

Kelly, R.L., 1988. The three sides of a biface. American Antiquity 53, 717-734. Kuhn,

S.-L., 1992. On planning and curated technologies in the Middle Paleolithic.

J ournal of Anthropological Research 48, 185-213.

Kuhn, S.-L., 1995. Mousterian Lithic Technology. An Ecological Perspective. Princeton University Press, Princeton.

Lenoir, M., 1986. Un mode de retouche "Quina" dans le Moustérien de CombeGrenal (Domme, Dordogne). Bulletin de la Société Anthropologique du Sudouest 21 , 153-160.

Le Tensorer, J.-M., 1978. Le Moustérien de type Quina et son évolution dans le Sud de la France. Bulletin de la SociétéPréhistorique Française 75, 141-169.

Locht, J .-L., Swinnen, C., 1994. Le débitage discoïde du gisement de Beauvais (Oise): aspect dela chaîneopératoire au travers dequelques remontages. Paléo 6, 89-104.

Marean, C.W., Kim, S.Y., 1998. Mousterian large-mammal remains from Kobeh cave: behavioral implications for Neanderthals and early modern humans. Current Anthropology 39 (2), S79-S113.

Maureille, B., 2010. Les Pradelles à Marillac-le-franc (Charente). Fouilles 2001-2007: nouveaux résultats et synthèse. In: Buisson-Catil, J., Primault, J. (Eds.), Préhistoire entre Vienne et Charente. Hommes et sociétés du Paléolithique. Association des Publications Chauvinoises, Chauvigny, pp. 145-162.

McPherron, S., Talamo, S., Goldberg, P., Niven, L., Richards, M., Sandgathe, D., Dibble, H.L, 2012. AMS ${ }^{14} \mathrm{C}$ Dates for the Late Middle Paleolithic at Pech de l'Azé IV, France. J ournal of Archaeological Science 39 (11), 3436-3442.

Meignen, L., 1995. Levallois lithic production systems in the Middle Paleolithic of the Near East: the case of the unidirectional method. In: Dibble, H.L., BarYosef, O. (Eds.), The Definition and Interpretation of Levallois Technology. Prehistory Press, Madison, pp. 161-379.

Mellars, P.-A., 1965. Sequence and development of Mousterian traditions in Southwestern France. Nature 205, 626-627.

Mellars, P.-A., 1969. The chronology of Mousterian industries in the Périgord region of south-west France. Proceedings of the Prehistoric Society 35, 134-171

Mellars, P.-A., 1970. Some comments on the notion of "functional variability" in stone-tool assemblages. World Archaeology 2, 74-89.

Mellars, P.-A., 1988. The chronology of the southwest French Mousterian: a review of the current debate. In: Otte, M. (Ed.), L'Homme de N'endertal, La Technique, vol. 4. ERAUL, Liege, pp. 97-120.

Mellars, P.-A., 1989. Chronologie du Moustérien du sud-ouest de la France : actualisation du débat. L'Anthropologie 94, 1-18.

Mellars, P.-A., 1992. Technological change in the Mousterian of southwest France. In: Dibble, H.L., Mellars, P.A. (Eds.), The Middle Palaeolithic: Adaptation, Behavior, and Variability. University of Pennsylvania, University Museum Monographs $\mathrm{n}^{\circ}$ 72, Philadelphia, pp. 29-43.

Mellars, P.-A., 1996. The Neanderthal Legacy. An Archaeological Perspective from Western Europe. Princetown University Press, New York

Otte, M., Boëda, E., Haesaerts, P., 1990. Rocourt: industrie laminaire archaïque. Héinium XXIX (1), 3-13

Panabieres, F., 1989. Etude techno-typologique des racloirs de la couche 35 de Combe-Grenal. Diplome d'Etudes Approfondies en Anthropologie. Universitéde Bordeaux I, France.

Pelegrin, J., 1990. Observations technologiques sur quelques séries du ChAtelperronien et du MTA B du sud-ouest de la France: une hypothèse d'évolution. In: Farizy C. (Ed), Paléolithique Moyen Récent et Paléolithique Supérieur Ancien en Europe, Nemours, Mémoires du Musée de Préhistoire d'Ile de France $\mathrm{n}^{\circ} 3$, pp. 195-201.

Peresani, M., 1998. La variabilité du débitage discoïde dans la grotte de Fumane (Italie du Nord). Paléo 10, 123-146.

Revillion, S., 1995. Technologie du débitage laminaire au Paléolithique moyen en Europe septentrionale: état de la question. Bulletin de la Société Préhistorique Française 95, 425-441.

Richter, D., Dibble, H., Goldberg, P., McPherron, S.P., Niven, L., Sandgathe, D. Talamo, S., Turq, A., 2013a. The late Middle Palaeolithic in Southwest France: newTL dates for the sequence of Pech de l'AzéIV. Quaternary International 294, 160-167.

Richter, D., Hublin, J .-J ., J aubert, J., McPherron, S.P., Soressi, M., Texier, J .-P., 2013b. Thermoluminescence dates for the Middle Palaeolithic site of Chez-Pinaud J onzac (France). J ournal of Archaeological Science 40, 1176-1185.

Rolland, N., 1981. The interpretation of Middle Palaeolithic variability. Man 16, 15-42.

Rolland, N., 1988. Variabilité et classification: nouvelles données sur le " complexe moustérien ». In: Otte, M. (Ed.), L'Homme de N'endertal, La Technique, vol. 4. ERAUL, Liëge, pp. 169-183. 
Rolland, N., Dibble, H.-L., 1990. A new synthesis of middle Paleolithic assemblage variability. American Antiquity 55, 480-499.

Sánchez-Goni, M.F., Landais, A., Fletcher, W.J., Naughton, F., Desprat, S., Duprat, J. 2008. Contrasting impacts of Dansgaard-Oeschger events over a western European latitudinal transect modulated by orbital parameters. Quaternary Science Reviews 27, 1136-1151.

Scott, B., 2011. Becoming Neanderthals: the Earlier British Middle Palaeolithic. Oxbow Books, Oxford

Soressi, M., 2002. Le Moustérien de tradition acheuléenne du sud-ouest de la France. Discussion sur la signification du faciès à partir de l'étude comparée de quatre sites : Pech-de-l'AzéI, Le Moustier, La Rochette et la Grotte XVI. (Ph.D. thesis). Universitéde Bordeaux I, France.

Steele, T.E., 1999. Variation in mortality profiles of red deer (Cervus elaphus) in Middle Palaeolithic assemblages from Western Europe. International J ournal of Osteology 14, 307-320.

Thiebaut, C., 2005. Le Moustérien à denticulés: variabilité ou diversité technoéconomique? (Ph.D. thesis) Université Aix-Marseilles I, Université de Provence France.

Turq, A., 1988. Le Moustérien de type Quina du Roc de Marsal à Campagne (Dordogne). Document d'Archéologie Périgourdine (ADRAP) t. 3, 5-30.
Turq, A., 1989. Approche technologique et économique du faciès Moustérien de type Quina: étude prédiminaire. Bulletin de la Sociéé Préhistorique Française $86,244-256$.

Turq, A. 1979. L'évolution du Moustérien de type Quina au Roc-de-Marsal et en Périgord: modifications de l'équilibre technique et typologique. Mémoire de l'EHESS, Toulouse.

Turq, A., 1992. Raw material and technological studies of the Quina Mousterian. In Dibble, H.-L., Mellars, P.A. (Eds.), The Middle Palaeolithic : Adaptation, Behavior and Variability. University of Pennsylvania, University Museum Monographs n 72, Philadelphia, pp. 75-85

Turq, A. 2000. Paléolithique inférieur et moyen entre Dordogne et Lot. Paléo, Supplément $\mathrm{n}^{\circ} 2$.

Turq, A., Roebroeks, W., Bourguignon, L., Faivre, J .-P., 2013. The fragmented char acter of Middle Palaeolithic stone tool technology. J ournal of Human Evolution in press, available online.

Van Peer, P., 1992. The Levallois Reduction Strategy. Prehistory Press, Madison. Viellevigne, E., Guibert, P., 2007. Datations par thermoluminescence d'un silex du Paleolithique moyen des Pradelles. Unpublished report.

Vincent, A., 1993. L'outillage osseux au Paléolithique moyen: une nouvelle approche (Ph.D. thesis). UniversitéParis X, France 